\section{Familiar factors and illicit drug use among Brazilian adolescents: an analysis of the Brazilian National Survey of School Health (PeNSE, 2015)}

\author{
O uso de drogas ilícitas e fatores familiares entre \\ adolescentes brasileiros: uma análise da Pesquisa \\ Nacional de Saúde Escolar (PeNSE, 2015)
}

Factores familiares y consumo de drogas ilícitas entre adolescentes brasileños: un análisis de la Encuesta Nacional de Salud Escolar (PeNSE, 2015)
Hellen de Araújo Antunes 1

María Fernanda Rivadeneira-Guerrero 2 Bárbara Niegia Garcia de Goulart 1 Nágila Soares Xavier Oenning 1

doi: 10.1590/0102-311X00009518

\author{
Correspondence \\ N. S. X. Oenning \\ Universidade Federal do Rio Grande do Sul. \\ Rua Ramiro Barcelos 2400, 20 andar, Porto Alegre, RS \\ 90035-003, Brasil. \\ nagilasx@gmail.com \\ 1 Universidade Federal do Rio Grande do Sul, Porto Alegre, \\ Brasil. \\ 2 Pontificia Universidad Católica del Ecuador, Quito, Ecuador.
}




\section{Introduction}

According to the World Health Organization (WHO), around 1.2 billion people are between 10 and 19 years old, meaning that 1 in every 6 people in the world is an adolescent. WHO points out that most of those adolescents are healthy; however, among other factors, the use of alcohol, tobacco and illicit drugs can put their health and life expectancy at risk, as well as those of future generations 1.

The indiscriminate consumption of illicit drugs by adolescents is a concern in many countries, as it reduces individuals' self-control, stimulating risk behaviors. In addition, it has a significant impact on the physical and social well-being of adolescents, being one of the main causes of disability and premature death in young people aged between 10 and 24 years 1,2 .

Research held in 17 countries from different continents showed variation in the age of initiation into drug use. It was observed that at age 15, in the United States and New Zealand, $42 \%$ of subjects reported having already tried cannabis; however, the initiation into cocaine occurred later, after 20 years 3.

Illicit drug use is related to both individual characteristics and social environments; nonetheless, the family environment also seems to be associated with this consumption 4. Parental practices such as monitoring, supervision, communication, support and engagement are protective factors to prevent the use of drugs 5 . Besides, there is an association between family problems, such as frequent discussions with parents along with the feeling that parents do not care about the adolescents, and illicit drug use ${ }^{6}$. In adolescence, family and relationships with parents play an important role in preventing the use of illegal substances 7 .

Parenting styles defined in two dimensions, control (supervision, demand and requirements) and responsibility (commitment to children, recognition and sensitivity), have a recognized effect on the behavioral development of young people 8,9 . The adolescents' relatives are the fundamental pillar for the development of the subjects' essential psychic processes, with the resulting formation of social and affective bonds that influence the rehabilitation process of individuals who use drugs 10 .

However, there is evidence that shows divergent results on the connection between substance use and relationship with parents. A study with adolescents living in Washington (USA) and Victoria (Australia) showed that family protection does not directly influence adolescents' consumption nor future harmful consequences 11 .

In this context, understanding the family environment as a variable that influences adolescent behavior, this study aimed at analyzing the association between the relationships with the parents or guardians, according with the adolescent's perceptions, and the illicit drug use among Brazilian students.

\section{Methods}

\section{Population and sample}

Cross-sectional study using data from the Brazilian National Survey of School Health (PeNSE, 2015) was carried out by the Brazilian Institute of Geography and Statistics (IBGE) along with the Brazilian Ministry of Health.

The target population was the school children from the day shift in the ninth grade of primary education (eighth year) in both public and private schools from all states in addition to the Federal District, with data collection conducted by IBGE agents, from April to September 201512.

Sampling was carried out in two stages in the capital cities (schools and class) and in three stages in the geographical strata formed by other cities (groups of cities, schools and classes). All the students who attended classes on the day of collection formed the sample 12.

A number of 229 out of the 102,301 students who answered the questionnaire were excluded, because they would prefer not participating in this research or did not inform gender or age. There were 102,072 students in this research, being 52,782 females and 49,290 males 12 .

Data was collected through a structured and self-administered questionnaire by smartphone, provided by those responsible for the research, with no previous interview. To characterize the 
studied population, the following variables were considered: sex, age, color, school type and geographic region 12 .

\section{Measures}

\section{- Outcome}

The dependent variable considered was the use of illicit drugs, which was obtained through the question: "In the last 30 days, how many times have you used drugs such as marijuana, cocaine, crack, glue, ecstasy, oxy or others?”. Response categories were dichotomized: I have never used drugs (no) and some frequency (yes).

\section{- Exposure}

For family relationship, the variables selected were the following: students who live with parents (categorized: yes/no); frequency with which students skipped classes without consent in the last 30 days (not once, 1-9 days, 10 or more); frequency with which students feel supervised by their guardians (always, sometimes, never); frequency with which students have their homework assignments checked by their guardians (always, sometimes, never); parents' understanding of their children's problems and concerns (always, sometimes, never); frequency with which students have meals with their guardians per week (every day, 3-6 days, 1-2 days, never); frequency with which students suffered physical aggression by family members in the last 30 days (not once, once, 2-5 times, 6 or more times); frequency with which students have felt supervised by parents/guardians (never, sometimes, always).

\section{- Confounding factors}

The adjustment variables (confounding factors) to multivariate models refer to sociodemographic characteristics, to parents and friends' profile, to adolescents' alcohol and smoking habits, as well as to their mental health.

The sociodemographic factors used for adjustment were: whether or not the adolescent works (categorized: yes/no); which type of school the student attends (public or private); student's age $(<12$, $13-15,16-18,19$ years or more); and variables about parents and friends' consumption: tobacco use by parents (categorized: yes/no) and drug use by friends (categorized: yes/no).

In the literature, a strong association between alcohol and tobacco consumption and illicit drug use by adolescents is observed 7,13,14,15,16, hence these variables were considered as model adjustment. The variables could be obtained through the following questions: "In the last 30 days, how often did you smoke cigarettes?" and "In the last 30 days, how often did you drink at least a glass or a dose of alcohol?". The answers were categorized into two possibilities: not once (no) and some frequency (yes).

For sensitivity analysis, some mental health-related variables were used, such as sleeping problems, feeling of loneliness (always, sometimes and never) and number of friends (0, 1, 2 or more friends).

\section{Statistical analysis}

Data analyses were performed in two stages: the first one examined the frequency of demographics by calculating the p-value for the chi-squared test. Multivariate analysis by Poisson regression was carried out, with a robust variance estimator to calculate the prevalence ratio (PR) and the 95\% confidence interval $(95 \% \mathrm{CI})$. As for the main model, two multivariate analyses were performed, one without adjustments for sociodemographic factors and another adjusted for these factors in addition to alcohol and tobacco use.

Sensitivity analysis was performed in order to observe the consistency of the model, considering the variables about mental health (if the students feel alone, have sleep problems and social interaction 
difficulties). All analyses were stratified by gender and performed by IBM SPSS software, version 21 (https://www.ibm.com/).

\section{Ethical issues}

The participation was voluntary, therefore, only the students who agreed with the Informed Consent Form took part in the research. They had the possibility of not answering a particular question or the whole questionnaire. The PeNSE, 2015, was approved by the National Commission for Research Ethics (n. 1006,467). It is important to emphasize that the research has a triennial cycle, started in 200912

\section{Results}

The total number of students was 102,072, being the majority female (51.7\%) and non-white (66.9\%). Most of the students (87.4\%) were between 13 and 15 years old and the smallest part was 12 years old or younger. Most of them (87.3\%) had no occupation, job or business and lived in the Northeast region of Brazil (35.6\%). A total of 79.54\% of the schools that took part in the research are public (Table 1).

Most adolescents do not live with parents who smoke (75.5\%), although a high percentage of them $(41.8 \%)$ report having friends who use illicit drugs. According to the survey, $22 \%$ of adolescents consume alcohol and 5.3\% have tried tobacco. Regarding mental health aspects, most of them never feel alone (55.3\%) and have more than two close friends (89.5\%). However, $36.2 \%$ of the adolescents reported having sleeping problems due to their everyday concerns. Differences in the percentage of factors were observed between sexes except for type of school (Table 1).

The general prevalence of illicit drug use was 3.8\%; being 3.3\% among females and $4.4 \%$ among males. As for the age, the bigger prevalence was found in girls between 16-18 years (5.9\%) and in boys aged less than or equal to 19 years $(9.1 \%)$.

The prevalence of illicit drug use according to the eight investigated variables concerning the adolescents' family relationship is shown in Table 2. The highest prevalence $(>2.0)$ was observed in adolescents (from both genders) who did not live with parents nor guardians, whose homework was never examined, who did not suffer any type of aggression by their family, and who did not report any invasion of privacy (Table 2).

Most adolescents live with their parents, do not skip classes without parents' consent, do not suffer domestic violence, share meals with parents and feel supervised and understood by them. They also claim that their privacy was almost never invaded. However, about $15 \%$ of adolescents experience domestic violence at least once a month and more than $40 \%$ of them do not receive support for school tasks (Table 2).

Table 3 presents the results of multivariate analyses for the associations of family factors with illicit drug use among boys and girls. The following factors increase the prevalence ratio for illicit drug use in adolescents: not to live with their parents, not to feel supervised by them and to skip classes without parents' consent. Never feeling understood by parents was also associated with illicit drug use, despite a borderline association.

Furthermore, frequent aggression episodes, having their privacy constantly invaded (regarding boys) were also associated with illicit drug use by adolescents. Considering adjustment factors, the use of drugs by friends was strongly associated with illicit drug use in adolescence (girls PR $=21.18$, 95\%CI: 14.69-30.53; and boys PR = 19.93, 95\%CI: 14.89-26.65). These findings were similar in both genders and the adjustment did not significantly affect the estimates, however, they modified the magnitude of the association.

Sensitive analysis, which included whether the adolescents feel alone, have difficulty to sleep and have a great number of friends did not significantly modify the expressive associations found in analysis adjusted to the family relationship and to the use of illicit drugs by Brazilian adolescents. 


\section{Table 1}

Descriptive statistics of population's characteristics and adjustment variables, by sex. Brazilian National Survey of School Health (PeNSE), 2015.

\begin{tabular}{|c|c|c|c|c|c|c|}
\hline & \multirow[t]{2}{*}{ Total } & \multicolumn{2}{|c|}{ Female } & \multicolumn{2}{|c|}{ Male } & \multirow[t]{2}{*}{ p-value } \\
\hline & & $\mathrm{n}$ & $\%$ & $n$ & $\%$ & \\
\hline \multicolumn{7}{|l|}{ Age (years) } \\
\hline$\geq 12$ & 538 & 324 & 0.6 & 214 & 0.4 & 0.000 \\
\hline $13-15$ & 89,197 & 47,315 & 89.7 & 41,882 & 85.0 & \\
\hline $16-18$ & 11,765 & 4,857 & 9.2 & 6,908 & 14.0 & \\
\hline$\leq 19$ & 572 & 286 & 0.5 & 286 & 0.6 & \\
\hline \multicolumn{7}{|l|}{ Color/Race * } \\
\hline Non-white & 68,189 & 35,956 & 68.2 & 32,233 & 65.5 & 0.000 \\
\hline White & 33,775 & 16,779 & 31.8 & 16,996 & 34.5 & \\
\hline \multicolumn{7}{|l|}{ Type of school } \\
\hline Public & 81,154 & 42,029 & 79.6 & 39,125 & 79.4 & 0.322 \\
\hline Private & 20,918 & 10,753 & 20.4 & 10,165 & 20.6 & \\
\hline \multicolumn{7}{|l|}{ Region } \\
\hline North & 23,937 & 12,218 & 23.1 & 11,719 & 23.8 & 0.000 \\
\hline Northeast & 36,334 & 19,371 & 36.7 & 16,963 & 34.4 & \\
\hline Southeast & 17,772 & 9,051 & 17.2 & 8,721 & 17.7 & \\
\hline South & 9,850 & 4,973 & 9.4 & 4,877 & 9.9 & \\
\hline Central & 14,179 & 7,169 & 13.6 & 7,010 & 14.2 & \\
\hline \multicolumn{7}{|l|}{ Work * } \\
\hline Yes & 12,851 & 4,502 & 8.5 & 8,349 & 17.0 & 0.000 \\
\hline No & 89,116 & 48,235 & 91.5 & 40,881 & 83.0 & \\
\hline \multicolumn{7}{|c|}{ Illicit drugs use by friends * } \\
\hline Yes & 35,793 & 18,801 & 42.7 & 16,992 & 40.9 & 0.000 \\
\hline No & 49,843 & 25,280 & 57.3 & 24,563 & 59.1 & \\
\hline \multicolumn{7}{|c|}{ Tobacco use by parents or guardians * } \\
\hline Just father & 12,942 & 6,886 & 13.3 & 6,056 & 12.7 & 0.000 \\
\hline Just mother & 7,620 & 4,274 & 8.3 & 3,346 & 7.0 & \\
\hline Mother and father & 3,800 & 2,102 & 4.1 & 1,698 & 3.5 & \\
\hline No & 75,098 & 38,347 & 74.3 & 36,751 & 76.8 & \\
\hline Alcohol use * & & & & & & 0.000 \\
\hline Yes & 22,597 & 12,140 & 23 & 10,457 & 21 & \\
\hline No & 79,364 & 40,593 & 77 & 38,771 & 79 & \\
\hline Tobacco use * & & & & & & 0.000 \\
\hline Yes & 5,417 & 2,587 & 4.9 & 2,830 & 5.7 & \\
\hline No & 96,596 & 50,176 & 95.1 & 46,420 & 94.3 & \\
\hline Number of friends * & & & & & & 0.000 \\
\hline 0 & 4,179 & 1,862 & 4.1 & 2,317 & 4.7 & \\
\hline 1 & 6,467 & 3,758 & 6.4 & 2,709 & 5.5 & \\
\hline 2 or more & 90,992 & 47,029 & 89.5 & 43,963 & 89.7 & \\
\hline Feel alone * & & & & & & 0.000 \\
\hline Always & 17,060 & 11,987 & 22.8 & 5,073 & 10.4 & \\
\hline Sometimes & 28,402 & 17,440 & 33.1 & 10,962 & 22.4 & \\
\hline Never & 56,206 & 23,236 & 44.1 & 32,970 & 67.3 & \\
\hline Sleeping problems * & & & & & & 0.000 \\
\hline Always & 11,699 & 8,230 & 15.6 & 3,469 & 7.1 & \\
\hline Sometimes & 25,064 & 15,501 & 29.4 & 9,563 & 19.6 & \\
\hline Never & 64,811 & 28,912 & 54.9 & 35,899 & 73.3 & \\
\hline
\end{tabular}

* Missing values. 
Table 2

Prevalence rates of use of illicit drugs among Brazilian adolescents, according to family factors, by sex. Brazilian National Survey of School Health (PeNSE), 2015.

\begin{tabular}{|c|c|c|c|c|c|c|c|}
\hline & \multirow[t]{2}{*}{$\mathbf{n}$} & \multicolumn{2}{|c|}{$\begin{array}{l}\text { Female } \\
(n=1,758)\end{array}$} & \multirow[t]{2}{*}{$\mathbf{n}$} & \multicolumn{2}{|c|}{$\begin{array}{c}\text { Male } \\
(n=2,157)\end{array}$} & \multirow[t]{2}{*}{ p-value } \\
\hline & & $\mathrm{n}$ cases & $\%$ & & $\mathrm{n}$ cases & $\%$ & \\
\hline \multicolumn{8}{|c|}{ Living with parents } \\
\hline Yes & 29,452 & 726 & 1.3 & 29,217 & 973 & 2.0 & 0.000 \\
\hline No & 23,330 & 1,032 & 2.0 & 20,073 & 1,184 & 2.4 & \\
\hline \multicolumn{8}{|c|}{ 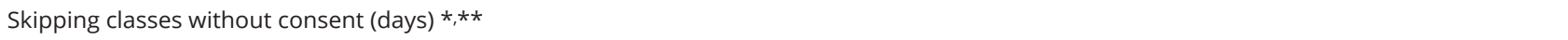 } \\
\hline No & 42,454 & 908 & 1.7 & 37,750 & 1,169 & 2.4 & 0.000 \\
\hline $1-9$ & 9,721 & 732 & 1.4 & 10,761 & 835 & 1.7 & \\
\hline 10 or more & 4,98 & 112 & 0.2 & 556 & 146 & 0.3 & \\
\hline \multicolumn{8}{|c|}{ Family supervision $*, \star \star$} \\
\hline Always & 36,140 & 705 & 1.3 & 31,075 & 754 & 1.5 & 0.000 \\
\hline Sometimes & 6,745 & 372 & 0.7 & 7,633 & 536 & 1.2 & \\
\hline Never & 9,701 & 674 & 1.3 & 10,240 & 852 & 1.7 & \\
\hline \multicolumn{8}{|c|}{ Verification of homework assignments *,** } \\
\hline Always & 15,569 & 329 & 0.6 & 16,860 & 509 & 1.0 & 0.000 \\
\hline Sometimes & 10,925 & 282 & 0.5 & 12,203 & 463 & 0.9 & \\
\hline Never & 26,115 & 1,140 & 2.2 & 19,912 & 1,169 & 2.4 & \\
\hline \multicolumn{8}{|c|}{$\begin{array}{l}\text { Parents' understanding of their children's problems and } \\
\text { concerns } *, \star *\end{array}$} \\
\hline Always & 21,138 & 426 & 0.8 & 22,429 & 668 & 1.4 & 0.000 \\
\hline Sometimes & 11,449 & 321 & 0.6 & 11,422 & 511 & 1.0 & \\
\hline Never & 20,004 & 1,006 & 1.9 & 15,055 & 964 & 2.0 & \\
\hline \multicolumn{8}{|c|}{ Physical aggression by family members (times) $*, \star \star$} \\
\hline Not once & 44,684 & 1,117 & 2.1 & 42,111 & 1,462 & 3.0 & 0.000 \\
\hline 1 & 3,867 & 210 & 0.4 & 2,704 & 184 & 0.4 & \\
\hline $2-5$ & 2,517 & 205 & 0.4 & 1,836 & 167 & 0.4 & \\
\hline 6 or more & 1,402 & 209 & 0.4 & 1,989 & 298 & 0.6 & \\
\hline \multicolumn{8}{|c|}{ Invasion of privacy $*, \star \star$} \\
\hline Never & 36,276 & 1,078 & 2.0 & 33,831 & 1,335 & 2.7 & 0.000 \\
\hline Sometimes & 9,468 & 349 & 0.7 & 8,956 & 404 & 0.9 & \\
\hline Always & 6,856 & 326 & 0.6 & 6,157 & 402 & 0.8 & \\
\hline \multicolumn{8}{|c|}{ 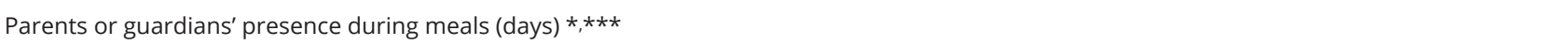 } \\
\hline Every & 34,743 & 882 & 1.7 & 35,759 & 1,220 & 2.5 & 0.000 \\
\hline $3-6$ & 3,723 & 155 & 0.3 & 3,867 & 235 & 0.5 & \\
\hline $1-2$ & 1,821 & 66 & 0.1 & 1,553 & 90 & 0.2 & \\
\hline No & 12,445 & 653 & 1.2 & 8,035 & 610 & 1.2 & \\
\hline
\end{tabular}

* Missing values;

** Last 30 days;

$\star * *$ Weekly. 
Table 3

Unadjusted (Model 1) and adjusted (Models 2 and 3) prevalence ratios (PR) and respective $95 \%$ confidence intervals (95\%Cl) for the association between family factors and use of illicit drugs, by sex. Brazilian National Survey of School Health (PeNSE), 2015.

\begin{tabular}{|c|c|c|c|c|c|c|c|c|c|c|c|c|}
\hline & \multicolumn{6}{|c|}{ Female } & \multicolumn{6}{|c|}{ Male } \\
\hline & \multicolumn{2}{|c|}{ Model 1 * } & \multicolumn{2}{|c|}{ Model $2 * *$} & \multicolumn{2}{|c|}{ Model $3 * * *$} & \multicolumn{2}{|c|}{ Model 1 * } & \multicolumn{2}{|c|}{ Model 2 ** } & \multicolumn{2}{|c|}{ Model $3 * * *$} \\
\hline & PR & $9 \% \% \mathrm{Cl}$ & PR & $95 \% \mathrm{Cl}$ & PR & $95 \% \mathrm{Cl}$ & PR & $95 \% \mathrm{Cl}$ & PR & $95 \% \mathrm{Cl}$ & PR & $95 \% \mathrm{Cl}$ \\
\hline \multicolumn{13}{|c|}{ Living with parents } \\
\hline Yes & 1.00 & & 1.00 & & 1.00 & & 1.00 & & 1.00 & & 1.00 & \\
\hline No & 1.41 & $1.28-1.55$ & 1.16 & $1.06-1.26$ & 1.19 & $1.08-1.30$ & 1.44 & $1.32-1.56$ & 1.14 & $1.06-1.23$ & 1.24 & $1.14-1.35$ \\
\hline \multicolumn{13}{|c|}{$\begin{array}{l}\text { Skipping classes without } \\
\text { consent (days) \# }\end{array}$} \\
\hline No & 1.00 & & 1.00 & & 1.00 & & 1.00 & & 1.00 & & 1.00 & \\
\hline $1-9$ & 2.50 & $2.26-2.76$ & 1.32 & $1.21-1.45$ & 1.79 & $1.62-1.98$ & 1.94 & $1.77-2.28$ & 1.13 & $1.05-1.23$ & 1.35 & $1.24-1.48$ \\
\hline 10 or more & 5.42 & $4.50-6.54$ & 1.70 & $1.43-2.01$ & 3.13 & $2.60-3.76$ & 4.69 & $3.98-5.52$ & 1.49 & $1.28-1.74$ & 2.51 & $2.11-2.99$ \\
\hline \multicolumn{13}{|c|}{ Family supervision \# } \\
\hline Always & 1.00 & & 1.00 & & 1.00 & & 1.00 & & 1.00 & & 1.00 & \\
\hline Sometimes & 1.95 & $1.72-2.12$ & 1.21 & $1.07-1.36$ & 1.61 & $1.42-1.83$ & 2.29 & $2.05-2.68$ & 1.31 & $1.18-1.45$ & 1.81 & $1.62-2.02$ \\
\hline Never & 2.17 & $1.95-2.43$ & 1.29 & $1.16-1.42$ & 1.80 & $1.62-2.01$ & 2.46 & $2.21-2.72$ & 1.40 & $1.28-1.63$ & 1.95 & $1.76-2.16$ \\
\hline \multicolumn{13}{|c|}{$\begin{array}{l}\text { Verification of homework } \\
\text { assignments \# }\end{array}$} \\
\hline Always & 1.00 & & 1.00 & & 1.00 & & 1.00 & & 1.00 & & 1.00 & \\
\hline Sometimes & 1.02 & $0.87-1.19$ & 0.99 & $0.86-1.14$ & 0.95 & $0.81-1.11$ & 1.04 & $0.92-1.18$ & 0.98 & $0.88-1.10$ & 0.97 & $0.85-1.09$ \\
\hline Never & 1.22 & $1.07-1.38$ & 0.98 & $0.87-1.10$ & 1.00 & $0.88-1.14$ & 1.24 & $1.11-1.39$ & 1.00 & $0.90-1.11$ & 1.02 & $0.92-1.14$ \\
\hline \multicolumn{13}{|c|}{$\begin{array}{l}\text { Parents' understanding of } \\
\text { their children's problems } \\
\text { and concerns \# }\end{array}$} \\
\hline Always & 1.00 & & 1.00 & & 1.00 & & 1.00 & & 1.00 & & 1.00 & \\
\hline Sometimes & 1.07 & $0.93-1.23$ & 0.97 & $0.85-1.11$ & 1.00 & $0.86-1.15$ & 1.11 & $0.99-1.24$ & 1.07 & $0.96-1.18$ & 1.04 & $0.93-1.16$ \\
\hline Never & 1.38 & $1.22-1.57$ & 1.11 & $1.00-1.25$ & 1.14 & $1.01-1.29$ & 1.24 & $1.11-1.37$ & 1.13 & $1.03-1.24$ & 1.17 & $1.05-1.29$ \\
\hline \multicolumn{13}{|c|}{$\begin{array}{l}\text { Physical aggression by } \\
\text { family members (time) \# }\end{array}$} \\
\hline Not once & 1.00 & & 1.00 & & 1.00 & & 1.00 & & 1.00 & & 1.00 & \\
\hline 1 & 1.47 & $1.27-1.70$ & 0.90 & $0.80-1.00$ & 1.10 & $0.95-1.28$ & 1.41 & $1.21-1.64$ & 0.98 & $0.86-1.12$ & 1.09 & $0.94-1.27$ \\
\hline $2-5$ & 1.96 & $1.70-2.27$ & 1.14 & $1.00-1.30$ & 1.37 & $1.18-1.59$ & 1.74 & $1.49-2.03$ & 1.10 & $0.96-1.27$ & 1.35 & $1.16-1.57$ \\
\hline 6 or more & 3.03 & $2.61-3.51$ & 1.39 & $1.21-1.59$ & 1.93 & $1.67-2.23$ & 2.59 & $2.29-2.92$ & 1.14 & $1.01-1.28$ & 1.63 & $1.43-1.85$ \\
\hline \multicolumn{13}{|c|}{ Invasion of privacy \# } \\
\hline Never & 1.00 & & 1.00 & & 1.00 & & 1.00 & & 1.00 & & 1.00 & \\
\hline Sometimes & 1.02 & $0.90-1.15$ & 0.99 & $0.89-1.10$ & 0.96 & $0.85-1.08$ & 1.05 & $0.94-1.17$ & 0.96 & $0.87-1.05$ & 1.01 & $0.90-1.12$ \\
\hline Always & 1.12 & $0.99-1.26$ & 1.02 & $0.92-1.14$ & 0.93 & $0.82-1.05$ & 1.48 & $1.32-1.65$ & 1.16 & $1.05-1.28$ & 1.27 & $1.13-1.42$ \\
\hline \multicolumn{13}{|c|}{$\begin{array}{l}\text { Parents or guardians' } \\
\text { presence during meals } \\
\text { (days) \#\# }\end{array}$} \\
\hline Every & 1.00 & & 1.00 & & 1.00 & & 1.00 & & 1.00 & & 1.00 & \\
\hline $3-6$ & 1.50 & $1.27-1.77$ & 1.23 & $1.06-1.43$ & 1.33 & $1.13-1.56$ & 1.65 & $1.45-1.89$ & 1.26 & $1.13-1.41$ & 1.43 & $1.26-1.63$ \\
\hline $1-2$ & 1.14 & $0.89-1.46$ & 1.02 & $0.81-1.27$ & 1.05 & $0.82-1.35$ & 1.47 & $1.20-1.81$ & 1.25 & $1.03-1.51$ & 1.24 & $1.01-1.52$ \\
\hline No & 1.18 & $1.06-1.31$ & 0.95 & $0.87-1.05$ & 1.01 & $0.91-1.13$ & 1.45 & $1.31-1.60$ & 1.09 & $1.00-1.19$ & 1.14 & $1.03-1.27$ \\
\hline
\end{tabular}

* Multivariate model 1 (unadjusted model) = family factors ( male $n=48,154$; female $n=52,089$ );

** Multivariate model 2 (adjusted model) $=$ family factors + sociodemographic factors + tobacco and alcohol use (male $n=39,829 ;$ female $n=42,749$ );

$* * *$ Multivariate model 3 (adjusted model) $=$ family factors + health mental factors ( male $n=39,774$; female $n=42,716$ );

\# Last 30 days;

\#\# Weekly. 


\section{Discussion}

Prevalence of illicit drug use among Brazilian adolescents in this study was 3.8\%, similar to the one found in other American countries 3,4. However, this rate is still lower than the prevalence of consumption in the United States, which reaches $21.7 \%$ of the students who use marijuana ${ }^{17}$. The higher prevalence of male consumption than of female is in accordance with the results found in other studies worldwide 2,17. However, there is a tendency to homogenize consumption habits between genders 18,19 since a great difference between them was not found. Likewise, the prevalence of consumption follows a pattern that increases with the age of the adolescents 18,19 . The family context is the one that influences the most the initiation into use of substances in adolescents when compared to school and neighborhood contexts. In this research, we found that the absence of the father or of the mother in the household increased the illicit drug use in $16 \%$ for females and in $14 \%$ for males. Studies show that family's supervision is an important factor in avoiding the use of alcohol, tobacco and illicit drugs 20,21. In our study, this was significant for both genders, with a prevalence of 1.29 and 1.40 in female and male adolescents who never received family supervision when compared to those who always receive protection by the family.

Parental behavior that shows little responsibility for their children, as the parents' inability to understand their children's problems, are related to illicit drug use in the adolescents evaluated. The prevalence of adolescents who consume illegal drugs was greater among those who reported that their parents have never understood them (1.11 and 1.13 times higher in females and males, respectively) when compared to those who were always understood by parents. Nonetheless, excessive controlling attitudes, such as the invasion of privacy by parents, were also associated with illicit drug use. In our study, there was a higher prevalence of consummation in adolescents who always have their privacy invaded by parents, but this association was significant among males, not among females. The adolescents have reported, among other factors, that the lack of structure and family support are some of the reasons why they have started using illicit drugs 22,23 . On the other hand, several other factors of family protection to prevent drug use are mentioned in studies, such as demonstrations of affection toward children, easy communication, adequate flexibility in the creation and application of rules 6,24,25.

It is important to mention the association found in this study between physical aggression suffered by the adolescents from their family members and illicit drug use. The higher the frequency of physical aggression by the family, the higher the illicit drug use among adolescents. The study showed that this connection was 1.39 times greater in females and 1.14 times higher in males, being rather significant after adjustment for socioeconomic status as well as when it was independent of the simultaneous consumption of alcohol and tobacco. It has been shown that living in a family environment with a high level of conflict leads to the development of problematic behaviors in adolescents and influences substance abuse 26 . Exposure to an adverse and abusive family environment during childhood predicts substance use during adolescence 27 . Moreover, tobacco consumption by parents was positively associated with illicit drug use in male adolescents ( $\mathrm{PR}=1.22$, 95\%CI: 1.06-1.39), corroborating what was mentioned in other studies $16,28,29$, but was not significant for females.

The results of this study suggest an important role of the family context and parental behavior on adolescents' habits. This role does not depend on the adolescents' age, gender, type of school or work. Furthermore, this association was consistent when we considered adolescents' alcohol and tobacco consumption. This also had a very strong association with drug consumption by the adolescent's friends. This phenomenon was similar in both sexes, with a prevalence 21.18 times higher in females and 19.93 times higher in males when their friends consumed illegal drugs. Even though these variables were considered, the relationship with the family maintained a direct and significant association with illicit drug use in adolescents. Given the strong association with drug use by friends, it is necessary to emphasize this finding for future research and preventive measures. 


\section{Limitations and conclusion}

This study uses strong data, based on a nationwide survey, conducted every three years in Brazil. The data are representative for the Brazilian adolescent school population, the survey has internal validation and the results are consistent with the evidence described in the literature on adolescent drug use. However, it also has limitations, since it is not possible to make inferences of cause and effect, given its cross-sectional design and the use of secondary data and data collected. This happens because the results found depended on the perceptions and responses provided by the adolescents. In addition, the possible estimation of associations was due to sample size. However, it is important to emphasize that the results were consistent across the different models of analysis applied and there was no significant change in the results, even after it was adjusted by socioeconomic factors, concomitant consumption of alcohol and tobacco, and mental health characteristics.

In conclusion, the results of this study show the relevance the family has in the use of illicit drugs by Brazilian adolescents, considering sociodemographic and mental health factors in addition to alcohol and tobacco use. Despite the strong association between illicit drug use by friends and illicit drug use by adolescents, the relationship with the family has a direct and significant role in the use of drugs in Brazilian adolescent's schools. The results of the study suggest that it is necessary to take into account the relationship with the family when designing and implementing policies and strategies aimed at limiting the initiation into and use of drugs in adolescents.

\section{Contributors}

H. A. Antunes designed the study, managed the literature searches of previous related research and abstracts, and wrote the first draft of the manuscript. M. F. Rivadeneira-Guerrero managed the literature searches of previous related research and abstracts, reviewed the statistical analysis and the final manuscript. B. N. G. Goulart designed the study, managed the literature searches of previous related research and abstracts, reviewed the statistical analysis and the final manuscript. N. S. X. Oenning designed the study, managed the literature searches of previous related research and abstracts, conducted the statistical analysis and reviewed the final manuscript.

\section{Acknowledgments}

To the Department of Health and Human Communication, Federal University of Rio Grande do Sul (UFRGS) for the support in tutoring the analysis of the subject and presentation of epidemiological data.

\section{References}

1. World Health Organization. Adolescents: health risks and solutions. http://www.who. int/mediacentre/factsheets/fs345/en/\# (accessed on 17/Sep/2017).

2. Gore FM, Bloem PJ, Patton GC, Ferguson J, Joseph V, Coffey C, et al. Global burden of disease in young people aged 10-24 years: a systematic analysis. Lancet 2011; 377:2093-102.

3. Degenhardt L, Chiu W-T, Sampson N, Kessler RC, Anthony JC, Angermeyer M, et al. Toward a global view of alcohol, tobacco, cannabis, and cocaine use: findings from the WHO World Mental Health Surveys. PLoS Med 2008; 5:e141.

4. Bitancourt T, Tissot MCRG, Fidalgo TM, Galduróz JCF, Silveira Filho DX. Factors associated with illicit drugs' lifetime and frequent/ heavy use among students results from a population survey. Psychiatry Res 2016; 237: 290-5.

5. Paiva FS, Ronzani TM. Estilos parentais e consumo de drogas entre adolescentes: revisão sistemática. Psicol Estud 2009; 14:177-83.

6. Malbergier A, Cardoso LRD, Amaral RA. Uso de substâncias na adolescência e problemas familiares. Cad Saúde Pública 2012; 28:678-88.

7. Medina Arias N, Ferriani MGC. Factores protectores de las familias para prevenir el consumo de drogas en un municipio de Colombia. Rev Latinoam Enferm 2010; 18(Spe):504-12.

8. Rothrauff TC, Cooney TM, An JS. Remembered parenting styles and adjustment in middle and late adulthood. J Gerontol B Psychol Sci Soc Sci 2009; 64B:137-46. 
9. Steinberg L, Lamborn SD, Darling N, Mounts NS, Dornbusch SM. Over-time changes in adjustment and competence among adolescents from authoritative, authoritarian, indulgent, and neglectful families. Child Dev 1994; 65:754-70.

10. Schenker M, Minayo MCS. A importância da família no tratamento do uso abusivo de drogas: uma revisão da literatura. Cad Saúde Pública 2004; 20:649-59.

11. Kim MJ, Mason WA, Herrenkohl TI, Catalano RF, Toumbourou JW, Hemphill SA. Influence of early onset of alcohol use on the development of adolescent alcohol problems: a longitudinal binational study. Prev Sci 2017; 18:111.

12. Oliveira MM, Campos MO, Andreazzi MAR, Malta DC, Oliveira MM, Campos MO, et al. Características da Pesquisa Nacional de Saúde do Escolar - PeNSE. Epidemiol Serv Saúde 2017; 26:605-16.

13. Rosa MI, Caciatori JFF, Panatto APR, Silva BR, Pandini JC, Freitas LBS, et al. Uso de tabaco e fatores associados entre alunos de uma universidade de Criciúma (SC). Cad Saúde Colet (Rio J.) 2014; 22:25-31.

14. Rothman EF, Edwards EM, Heeren T, Hingson RW. Adverse childhood experiences predict earlier age of drinking onset: results from a representative US sample of current or former drinkers. Pediatrics 2008; 122:e298-304.

15. Bucholz KK, McCutcheon VV, Agrawal A, Dick DM, Hesselbrock VM, Kramer JR, et al. Comparison of parent, peer, psychiatric, and cannabis use influences across stages of offspring alcohol involvement: evidence from the COGA prospective study. Alcohol Clin Exp Res 2017; 41:359-68.

16. Gaete J, Olivares E, Rojas-Barahona CA, Rengifo MJ, Labbé N, Lepe L, et al. Consumo de tabaco y alcohol en adolescentes de 10 a 14 años de la ciudad de San Felipe, Chile: prevalencia y factores asociados. Rev Méd Chile 2016; 144:465-75.

17. Kann L, McManus T, Harris WA, Shanklin SL, Flint KH, Hawkins J, et al. Youth Risk Behavior Surveillance - United States, 2015. MMWR Surveill Summ 2016; 65:1-174.

18. Malbergier A, Cardoso LRD, Abrantes do Amaral R, Santos VCV. Gender parity and drug use: are girls catching up with boys? Rev Bras Psiquiatr 2012; 34:16-23.

19. Horta RL, Horta BL, Costa AWN, Prado RR, Oliveira-Campos M, Malta DC. Lifetime use of illicit drugs and associated factors among Brazilian schoolchildren, National Adolescent School-based Health Survey (PeNSE 2012). Rev Bras Epidemiol 2014; 17 Suppl 1:31-45.
20. Wen M. Social capital and adolescent substance use: the role of family, school, and neighborhood contexts. J Res Adolesc 2017; 27:362-78

21. Walsh SD, Djalovski A, Boniel-Nissim M, Harel-Fisch Y. Parental, peer and school experiences as predictors of alcohol drinking among first and second generation immigrant adolescents in Israel. Drug Alcohol Depend 2014; 138:39-47.

22. Bittencourt ALP, França LG, Goldim JR. Adolescência vulnerável: fatores biopsicossociais relacionados ao uso de drogas. Rev Bioét (Impr.) $2015 ; 23: 311-9$.

23. Riofrío Guillén R, Nascimento LC. Consumo de drogas en los jóvenes de la ciudad de Guayaquil, Ecuador. Rev Latinoam Enferm 2010; 18(Spe):598-605.

24. Cid-Monckton P, Pedrão LJ. Factores familiares protectores y de riesgo relacionados al consumo de drogas en adolescentes. Rev Latinoam Enferm 2011; 19(Spe):738-45.

25. Skeer MR, Yantsides KE, Eliasziw M, CarltonSmith A, Tracy M, Spirito A. Testing a brief substance misuse preventive intervention for parents of pre-adolescents: feasibility, acceptability, preliminary efficacy. J Child Fam Stud 2016; 25:3739-48.

26. Skeer M, McCormick MC, Normand S-LT, Buka SL, Gilman SE. A prospective study of familial conflict, psychological stress, and the development of substance use disorders in adolescence. Drug Alcohol Depend 2009; 104:65-72.

27. Cornelius MD, De Genna N, Goldschmidt L, Larkby C, Day N. Adverse environmental exposures during gestation and childhood: predictors of adolescent drinking. Subst Use Misuse 2016; 51:1253-63.

28. Scherrer JF, Xian H, Pan H, Pergadia ML, Madden PAF, Grant JD, et al. Parent, sibling and peer influences on smoking initiation, regular smoking and nicotine dependence. Results from a genetically informative design. Addict Behav 2012; 37:240-7.

29. Abreu MNS, Souza CF, Caiaffa WT. Tabagismo entre adolescentes e adultos jovens de Belo Horizonte, Minas Gerais, Brasil: influência do entorno familiar e grupo social. Cad Saúde Pública $2011 ; 27: 935-43$. 


\section{Resumo}

O uso de drogas ilícitas está associado a características individuais; no entanto, os ambientes social e familiar também parecem estar relacionados a esse consumo. O estudo teve como objetivo analisar as associações entre o relacionamento dos pais e responsáveis com os filhos adolescentes que usam drogas ilícitas no Brasil. Este foi um estudo transversal com dados da Pesquisa Nacional de Saúde Escolar (PeNSE, 2015), em que a populaçãoalvo foram escolares da nona série (oitavo ano). $O$ estudo incluiu 102.072 alunos (52.782 meninas e 49.290 meninos). O uso de drogas ilícitas foi a variável de desfecho, e os fatores de relacionamento familiar foram as variáveis de exposição. As variáveis de ajuste incluíram características sociodemográficas, saúde mental, tabagismo e consumo de álcool. Análises univariada e multivariada, estratificadas por sexo, foram realizadas com regressão de Poisson com variância robusta para calcular a razão de prevalências com intervalo de $95 \%$ de confiança. A prevalência global de uso de drogas ilícitas foi de 3,8\% (3,3\% para meninas e 4,4\% para meninos). Os seguintes fatores estiveram associados ao aumento da razão de prevalências para uso de drogas ilícitas em adolescentes: não viver com os pais, não se sentir supervisionado pelos pais, faltar à escola sem o consentimento dos pais, nunca se sentir compreendido pelos pais e relatos de agressões frequentes por familiares. As relações familiares problemáticas contribuem para o uso de drogas ilícitas entre adolescentes brasileiros, considerando também fatores sociodemográficos, tabagismo, uso de álcool e os perfis de uso pelos pais e amigos.

Saúde do Adolescente; Saúde Mental; Drogas Ilícitas; Relações Familiares

\section{Resumen}

El consumo de drogas ilícitas está relacionado con características individuales; no obstante, el entorno social y familiar parecen estar asociados con este consumo. El objetivo de este estudio fue analizar la asociación de las relaciones entre padres o tutores y adolescentes brasileños que consumen drogas ilícitas. Es un estudio transversal con datos procedentes de la Encuesta Nacional de Salud Escolar (PeNSE, 2015), donde la población objetivo fueron adolescentes en edad escolar en noveno curso (octavo año). Se incluyeron a un total de 102.072 estudiantes en esta investigación, siendo 52.782 mujeres y 49.290 hombres. El consumo ilícito de drogas fue el resultado y los factores de relación de la familia fueron la exposición. Para los ajustes, se establecieron factores como: características sociodemográficas, salud mental, así como el consumo de tabaco y alcohol. Los análisis univariados y multivariados estratificados por sexo se realizaron a través de la regresión de Poisson, con un estimador de varianza robusta para calcular el ratio de prevalencia y el intervalo de $95 \%$ de confianza. La prevalencia general en el consumo de drogas ilicitas fue 3, 8\%; 3,3\% entre mujeres y 4,4\% entre hombres. Los siguientes factores incrementan el ratio de prevalencia en el consumo de drogas ilícitas con adolescentes: no estar viviendo con sus padres, no sentirse supervisado por sus padres, $y$ saltarse clases sin el consentimiento de sus padres. El no sentirse nunca comprendido por sus padres, $y$ sufrir agresiones físicas frecuentes por parte de miembros de la familia, también estuvo asociado con el consumo ilícito de drogas. Las relaciones de familia asocian con el consumo ilícito de drogas entre adolescentes brasileños, considerando sus factores sociodemográficos, $y$ los perfiles de padres $y$ amigos en cuanto al consumo de alcohol y tabaco.

Salud del Adolescente; Salud Mental; Drogas Ilícitas; Relaciones Familiares
Submitted on $18 / \mathrm{Jan} / 2018$

Final version resubmitted on $24 / \mathrm{Jul} / 2018$

Approved on 15/Aug/2018 